\title{
Erratum to: Role of PD-1 in Immunity and Diseases
}

\author{
Kenji Chamoto, Muna Al-Habsi and Tasuku Honjo
}

\section{Erratum to:}

Chapter "Role of PD-1 in Immunity and Diseases"

in: A. Yoshimura (ed.), Emerging Concepts Targeting

Immune Checkpoints in Cancer and Autoimmunity, Current Topics in Microbiology and Immunology 410, https://doi.org/10.1007/82_2017_67

The original version of the book was inadvertently published without the sources for Figures 1, 4-6 in Chapter "Role of PD-1 in Immunity and Diseases", which have been now included as follows:

Figure 1: Márquez-Rodas et al. (2015) Immune checkpoint inhibitors: therapeutic advances in melanoma. Ann Transl Med. 3: 267

Figure 4: Chunyang L, Xu X, Wang H and Wei B (2012) PD-1 and CTLA-4 mediated inhibitory Signaling for $\mathrm{T}$ cell exhaustion during chronic viral infections. Clin Cell Immunol S12:010

Figure 5: Freeman GJ, Wherry EJ, Ahmed R, and Sharpe AH. Sharpe (2006) Reinvigorating exhausted HIV-specific T cells via PD-1-PD-1 ligand blockade. J Exp Med. 203: 2223

Figure 6: Dunn GP, Bruce AT, Ikeda H, Old LJ and Schreiber RD (2002) Cancer immunoediting: from immune-surveillance to tumor escape. Nat Immunol 3: 991

The missing figure sources have now been included in the chapter.

The updated online version of this chapter can be found at https://doi.org/10.1007/82_2017_67

Current Topics in Microbiology and Immunology (2017) 410:E1

https://doi.org/10.1007/978-3-319-68929-6_69

(C) Springer International Publishing AG 2018 